\title{
Foreign Language Learning at a Technical University in the Modern Period
}

\author{
https://doi.org/10.3991/ijep.v10i6.13375
}

\author{
Luydmila Merkulova, Olga Martynova, Margarita Ivkina ${ }^{(凶)}$ \\ Samara National Research University, Samara, Russia \\ margarita.ivkinalgmail.com
}

\begin{abstract}
Introduction. The article is devoted to the problems of the foreign language learning at a technical university. The theoretical importance of the research is in the analysis of the existing language learning system at a technical university in light of a modern engineer's professional activity model's change. Grounding of certain corrections in the language learning system also provides the theoretical importance of the research. The practical importance of our research is in the modification of the existing language learning system based on the environmental and activity approaches.

Materials and Methods. While carrying out the research we used a complex of methods; that is: literature analysis, empiric and praxymetric methods, and a modeling method.

Results. 4 main types of an engineer's professional activity are defined in the engineer's activity model. These types correspond to the main activity types by M.S. Kagan's concept - value-motivating, cognitive, reorganizing and communicative activities. An engineer's activity results analysis led to discovering new features in the engineer's personality structure lying in the communicative competence role increase. Consequently, we have made a conclusion on the increasing demands to the students', masters', post-graduates' and academic researches' language proficiency. Foreign language proficiency should provide for the ability to participate in the international conferences, to attend foreign professors' lectures, and to take part in the students' exchange programs. All of the above presupposes rather high foreign language proficiency and requires a foreign language learning system creation. The authors analyzed language learning courses at a technical university and carried out a post-graduates' survey. As a result, lack of syllabuses being able to fill in the gaps in language proficiency and to support speech skills was found out. Basing on the conclusions mentioned above an extra multi-purpose and multi-level structure syllabus was worked out. The article also describes in detail a foreign language learning system developed by the Department of Foreign Languages and Russian as a Second Language in the general learning environment of a technical university, which acquires for the modernization and reaching the education level corresponding to the leading universities' level.

Conclusion: The learning environment created by the Department of Foreign Languages and Russian as a Second Language of Samara National Research University provides for the students' individual needs in foreign language proficiency satisfaction at various levels. The analysis of other Russian universities' sites shows its unique character.
\end{abstract}


Keywords-Educational space, communicative competence, speech activity, level of foreign language proficiency, system approach, environmental approach

\section{Introduction}

Foreign language learning at a technical university has been a research object of scientists, methodologists and foreign language teachers for many years. In numerous research papers language proficiency level at various profile universities is being analyzed, methods of forming students' personal qualities in the process of foreign language learning are being developed, learning methods and technologies are being advanced, variants of information technologies using for a complex of professionally meaningful competences forming are being suggested. Nevertheless, foreign language learning problems remain actual. This is especially actual at technical universities.

The subject of our research is the language learning system at a technical university during integration in the world education society.

The aim of our research is to systemize the existing language learning system at a technical university, to theoretically ground the necessity of making changes in the existing system and to experimentally check the changes introduced.

The tasks of the research are to analyze the engineering activity model in the modern conditions; to define the "Foreign Language" subject position in the future engineers' education system; to develop language learning courses system based on the environmental approach and to evaluate its efficiency.

\section{Materials and Methods}

To reach the aim of our research we used a complex of interrelated research methods adequate to its subject: pedagogical, psychological, methodological literature analysis; empirical methods (participant observation, testing, questionnaire surveys, self-estimation and expert judges' estimation); praximetrical methods (syllabus' content analysis); modeling.

The research was conducted at the federal autonomous higher education institution "Samara National Research University named after academician S.P. Korolyov". 130 first-year students specializing in Information Technologies and Applied Mathematics and Physics were involved in the research work.

\section{Results}

\subsection{Analyzing the engineering activity model in the modern conditions}

National research universities being organized in Russia urge to become the leading ones in the world ratings; therefore, active foreign language proficiency becomes extremely important. 
The purpose of a national research university is to prepare a modern competitive scientist or an engineer able to solve constantly appearing anthropogenic problems of the human civilization [1]. An engineer traditionally should be able to analyze a current situation, to find out problems and reveal their reasons; to find ways of their solution; to work out technologies for these solutions' practical realization; to analyze these solutions revealing their possible disadvantages $[2,3]$. An engineer's activity model (M.S. Kagan's concept) [4] corresponds to the main activities types including value-oriented, cognitive, reorganizing and communicative activity types.

The value-oriented activity type is based upon social values representing personal values in a certain period of time. Psychology deals with them as with a source of motivation [5]. In the modern period one of the professional activity motivation sources is a need to be successful. Scientists highlight five components of success: health, immediate surrounding harmony, positive emotions predomination, financial well-being and self-importance feeling [6]. Therefore, professional activity should facilitate reaching a success and its realization by a person.

An engineer's activity is forwarded to the social realm reorganization which has begun since the industrialization process start and resulted in a bulk of ecological problems and anthropogenic cataclysms. The future social realm reorganization should aim at the solution of the problems accumulated and be carried out in close interaction with the cognitive activity.

In the age of close international cooperation foreign language proficiency becomes an important condition of engineers' professional activity, and foreign language learning becomes especially prominent at technical universities.

\subsection{Defining the "Foreign Language" subject position in the future engineers' education system}

Foreign language proficiency presupposes the ability not only to read specific literature to keep up with the international level of knowledge, but also the ability to communicate orally (public presentations, participation in professional discussions in both formal and informal atmosphere). Such ability helps to realize a person's successfulness, his/her activity results' appreciation by foreign partners, increasing professional development motivation.

The foreign language proficiency importance is realized by students. We carried out a survey among 130 first-year students, which revealed the main reasons of a need to master a foreign language: a wish to know and understand native speakers' culture and mentality $(50 \%)$, career perspectives realization (49\%), a desire to find a job abroad $(25 \%)$.

$70 \%$ note that they would learn a foreign language, even if it was not included into the credit course. Besides, the majority of students find it enough to master only one language (70\%), though $25 \%$ would like learn at least one more foreign language. Thus, the survey results showed that social values interpreted by students' individual perception become an important motivation source for foreign language learning.

However, researches show that many technical universities graduates carrying out scientific research in perspective science and technology areas have difficulties with 
presenting their achievements at the international level and interacting with foreign partners, despite their good learning results. We carried out first-year post-graduates self-investigation concerning their foreign proficiency according to the European evaluation system (investigation included 60 persons having completed a compulsory foreign language course). The results showed that only $23 \%$ are ready to active interaction while completing professional tasks (Upper-Intermediate and Advanced levels). All the rest have certain difficulties understanding native speakers, and Elementary and PreIntermediate levels cause difficulties in expressing ideas due to lack of vocabulary and grammar knowledge. Then, self-investigation results were proved by the results of a foreign language proficiency test [7].

\subsection{Developing language learning courses system based on the environmental approach and to evaluate its efficiency}

At the Department of Foreign Languages and Russian as a Foreign Language of Samara University we created a language proficiency system targeted at the main goal achievement - a university graduate should be able to speak a foreign language fluently for social communication, for specific and academic purposes. According to the environmental approach to get a result we formed an environment able to influence individual's personality, life style and self-development. This environment means existence of niches representing possibilities' space developing a person and making a person use the niches [8]. "Niches" are the foreign language courses specially worked out according to the Federal Education Standards for Bachelors and Masters of Science. The Bachelors' course main goal is foreign language proficiency for social communication which is closely connected with the school syllabus. However, according to the traditional foreign language learning at a technical university, we begin professional language learning already at this level. Nowadays, innovation programs including base and advanced foreign language learning levels are worked out and give a teacher an opportunity to choose a level according to the students' individual needs. Each level is divided into modules finishing up with tests. These modules represent autonomous and logically complete blocks of information. They allow differentiating the syllabus and providing mastering a foreign language course on different levels depending on the Bachelors' needs. These modules help students autonomously get ready to each meeting with a teacher. The essence of the modular technology requires subject-subject relations between a teacher and students in the learning process [9]. A student may learn any module autonomously, at a convenient pace, and, if necessary, to pay more attention to the personally most difficult professional knowledge and learning skills. A teacher in this case stops being an information holder and becomes a consultant [10].

While choosing the content for a vocationally oriented language learning course at the Foreign Languages department of Samara University we include separate content elements at the levels of actual knowledge, language, speech and also factual and content material [11].

In each module we choose vocationally important topics for discussion and communication, and then fill them with the essential vocabulary. Next, we choose language or 
speech materials for active and passive mastering, and finally we choose the necessary information sources to support each module [12].

Having analyzed the existing foreign language learning system at a technical university, we have made the following conclusion: there are not enough possibilities for filling the gaps of school education and for communication skills development. That is why we organized an extra course, "Foreign Language for Intercultural Communication". The content of the multi-level syllabus is aimed at general cultural competences development (professional foreign language proficiency, social interaction proficiency, capability of systematic studying scientific literature). In accordance with Federal Act No.273, the program helps satisfy students' individual needs in intellectual and moral development [13]. Learning following this multi-level syllabus may be carried out either at one level, or discretely by sequential studying both the first and the second level [14]. Figure 1 represents the language learning system.

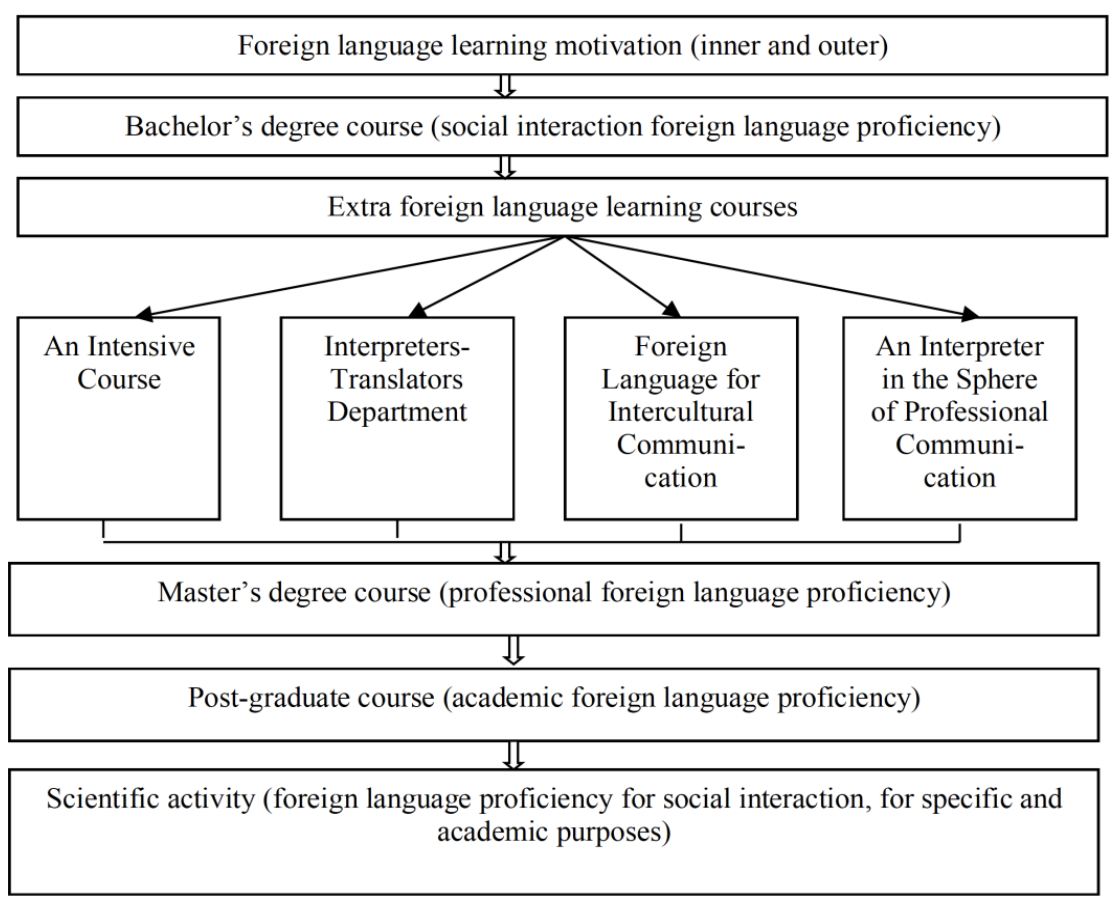

Fig. 1. A Foreign Language Learning System

Thus, the Foreign Languages Department's learning environment includes a compulsory language learning system according to the State Federal Educational Standards$3++$ and a system of extra professional education courses. Besides, our department provides an information environment helping organize students' individual work. This environment includes a regularly updated department's site with multiple tasks and tests for students' self-preparation and Moodle distance learning system with various language courses worked out by our department [15]. This environment is complemented 
with the possibilities of a university library, which is signed up for various foreign publications. All of these correspond to the main modern foreign language learning tendencies $[16,17$, and 18$]$.

Our department has also worked out a system of events including multi-level conferences and competitions.

Thus, our departments' learning environment language niches include a well-developed system of courses and events providing individual learning environment forming with access to real life.

\section{Conclusion}

As a result of our investigation it was found out that foreign language learning motivation has increased. The number of students desiring to attend our extra language learning courses has risen by $5 \%$ in comparison with the previous year. There appeared not only students, but also post-graduates and academic researches attending our courses to improve their language proficiency. Samara University widens its international contacts, opens double diplomas programs and organizes academic students' exchange.

In course of the research the following tasks were fulfilled:

1. The engineering activity model was analyzed, and it was defined that in the classical engineering activity model based on the types of activities theory the students' need to be successful in his/her professional activity becomes more and more important. This need is, in its turn, provided by a possibility to communicate in the worldwide professional association, and, consequently, by the level of the foreign language communicative competence.

2. The multi-level syllabuses' content analysis showed that the communicative competence is purposefully formed only at the foreign language learning classes. But at the same time, the existing in Russia foreign languages learning program presupposes a gap between Bachelors' and Masters' foreign language learning courses. That required additional foreign language learning courses' development, which provide language skills advancement.

3. The educational environment including compulsory language learning courses and additional multi-purpose language learning courses was developed as the answer to the students' needs revealed by the survey described in the article.

Thus, foreign language learning system being developed by our department is based on the system, environmental and activity approaches, and allows solving many problems of foreign language learning at a technical university. The system has a multilevel, multi-purpose structure and provides for increasing foreign language learning and general learning motivation. It creates conditions for self-development and self-realization and gets the students ready to take active part in academic and professional activities. 


\section{$5 \quad$ References}

[1] Galustyan O.V., Solyankin A.V., Skripkina A.V., Shchurov E.A., Semeshkina T.V., Ledeneva A.V., " Application of Blended Learning for Formation of Project Competence of Future Engineers", International Journal of Engineering Pedagogy, vol.10, №3 (2020), pp. 106-113, https://online-journals.org/index.php/i-jep/article/view/12251. https://doi.org/10. 3991/ijep.v10i3.12251

[2] F. Perels, T. Gürtler, B. Schmitz, "Training of self-regulatory-solving competence," Learning and instruction, vol. 15, pp. 123-139, 2005. https://doi.org/10.1016/j.learninstruc.2005. $\underline{04.010}$

[3] Martynova O.N. "Potencial samorealizacii budushchih inzhenerov: monografiya" [Future engineers' self-realization potential: monograph]. Samara, SSAU Publ., 2008. 204 p.

[4] Kagan M.S. Chelovecheskaya deyatel'nost'. (Opyt sistemnogo analiza) [Human's activity. (System analysis experience)]. Moscow, Politizdat, 1974. 328 p.

[5] Psihologiya. Slovar'/ Pod obshch. red. A.V. Petrovskogo, M.G. YAroshevskogo. - 2-e izd., ispr. i dop. [[Psychology. Dictionary / Under general editorship of Petrovskiy A.V., Jaroshevskiy M.G. $2^{\text {nd }}$ edition, revised and enlarged]. Moscow, Politizdat,1990. 494 p.

[6] Shcherbatyh Yu.V. Psihologiya uspekha [Successfulness psychology]. Moscow, Eksmo Publ., 2004. 560 p.

[7] Galway Cultural Institute's placement test. http://test.gci.ie/

[8] Manujlov Yu.S. Konceptual'nye osnovy sredovogo podhoda v vospitanii [Conceptual grounds of the environmental approach in upbringing] // Herald of the University of the Russian Academy of Education, 2003, №1, pp. 36-68.

[9] Ivana Simonova, "Learning Styles in Foreign Language Teaching/Learning", International Journal of Engineering Pedagogy, vol.1, №1 (2011), pp. 8-11, https://online-journals.org/index.php/i-jep/article/view/1587

[10] Vazina K.Ja. Samorazvitie cheloveka i modulnoe obuchenie [Human's self-development and modular education]. Nizhniy Novgorod, 1991. $191 \mathrm{p}$.

[11] Galskova N.D, Gez N.I. Teoriya obucheniya inostrannym yazykam. Lingvodidaktika $i$ metodika [Foreign languages learning theory. Language education and methodology]. Moscow, "Academia” Publ., 2006. 335 p.

[12] Ivkina M.V., Merkulova L.P. Module as a Structural Element in the Practice of Vocationally Oriented Foreign Language Learning for Bachelor of Science. [Modern Studies of Social Issues (E-magazine)]. Sovremennye issledovaniya social'nyh problem (Elektronnyj nauchnyj zhurnal). Krasnoyarsk: Obshchestvo s ogranichennoj otvetstvennost'yu «Nauchno-innovacionnyj centr», 2018, Vol.9, №2-2, pp. 5-15.

[13] Rossijskaya Federaciya. Zakony. Federal'nyj zakon ot 29 dekabrya 2012 g. № $273-\mathrm{FZ} « O b$ obrazovanii v Rossijskoj Federacii» [The Russion Federation. Laws. Federal Law from 29 Dec.2012 №273-FZ “On the education in the Russian Federation”]. http://base.garant.ru/70291362/. https://doi.org/10.2753/rsd1061-0014430301

[14] Martynova O.N. Yazykovaya podgotovka v tekhnicheskom vuze pri integracii v mirovoe obrazovatel'noe prostranstvo [Language learning at a technical university in the process of integration into the world education space]. Vestnik Samarskogo gosudarstvennogo tekhnicheskogo universiteta. Seriya: Psihologo-pedagogicheskie nauki, №4 (24), 2014, pp. 147-154.

[15] Ali Alharbi, Frans Henskens, Michael Hannaford, "Personalised Learning Object System Based on Self-Regulated Learning Theories", International Journal of Engineering Pedagogy, vol.4, № 3 (2014), pp. 24-35, https://online-journals.org/index.php/i-jep/issue/view/207. https://doi.org/10.3991/ijep.v4i3.3348 
[16] Easy English Communication at the Secondary Level: Easy Ways Teachers Who Are NonNative Speakers Can Use More English in Class - James R. Welker. Mie Prefectural Board of Education, Mie, Japan. http://iteslj.org/Articles/Welker-Communication.html. (in English).

[17] English Communication Through Practical Experiences. Judith D. DeRolf Kanto Gakuin. University Yokohama, Japan. http://iteslj.org/Articles/DeRolf-PracExper.html. (in English).

[18] What is EAP? Andy Gillett. http://www.uefap.com/bgnd/eap.htm. (in English).

\section{Authors}

Lyudmila P. Merkulova is a Professor, Doctor of Pedagogical Sciences, Head of Department of Foreign Languages and Russian as a Foreign Language at Samara National Research University, 34, Moskovskoye shosse, Samara, 443086, Russia.

Olga N. Martynova is a PhD (Pedagogical Sciences), Associate Professor of Department of Foreign Languages and Russian as a Foreign Language at Samara National Research University, 34, Moskovskoye shosse, Samara, 443086, Russia.

Margarita V. Ivkina is a PhD (Pedagogical Sciences), Associate Professor of Department of Foreign Languages and Russian as a Foreign Language at Samara National Research University, 34, Moskovskoye shosse, Samara, 443086, Russia. E-mail: margarita.ivkina@gmail.com

Article submitted 2020-01-23. Resubmitted 2020-08-18. Final acceptance 2020-08-24. Final version published as submitted by the authors. 